\title{
Transforming North African Feminisms from Within: New Post-Arab Spring Feminist Voices
}

\author{
Fatima Sadiqi*
}

\section{Introduction}

This article focuses on the 2010-2011 uprisings in North Africa ${ }^{1}$ as a 'revolution' instigated by new actors, and also by the new ambiguities that postcolonial rule in the region created. Women's rights in North Africa have been institutionally hyper-politicized and have served all sorts of agendas from the colonialist and neo-imperialist to the anti-colonialist and post-colonialist, to the religious extremist. ${ }^{2}$ This institutional instrumentalization has been first problematized then contested by generations of feminists and gender experts in the region. The lenses of these contestations were civil society, politics, and academia. My argument in this article may be stated as follows: Whereas the institutional instrumentalization of women's rights in North Africa has not undergone any substantial change, the issues addressed and contestation strategies and practices have dramatically changed in the post-revolution era. This is transforming feminisms and gender studies from within and in interesting ways, although the actors themselves do not always self-identify as feminists or gender experts. ${ }^{3}$ I address this argument conceptually and through facts. Conceptually, I adopt an overarching theoretical framework that I call "the Center" (Sadiqi 2016), an ideological shifting framework at the crossroads of culture, religion, and politics where diverse gender-based discourses converse. The fact that this space is gaining in vibrance even after the substantial weakening of the revolution means that it answers a real need at the publicdiscourse level which up to the pre-revolution moment was dominated by the secularist-Islamist frontal antagonism. The Center is yielding a new mind-set which seeks to highlight difference (whether linguistic, ideological, cultural, religious, educational, class-based, or gender-oriented), transgress the state's authority (in which it lost trust), and find new free ways of expression that are not constrained by (political) alliances. In these emerging dynamics, gender is central, both as a defining marker/discourse and a way of reconfiguring space. To understand these new developments, this article is divided into four main

\footnotetext{
* Sidi Mohamed Ben Abdellah University, Fez, Morocco.

Cairo Studies in English (2018): https://cse.journals.ekb.eg/
} 
sections. The first section presents the relevant aspects of the Center; the second one summarizes the salient ways in which the state instrumentalized women's rights in the pre-revolution era; the third one presents a note on methodology and the new female voices; and the fourth section provides my own readings of the emerging voices. In the conclusion, I revisit the Center framework and show ways in which this framework can help us understand post-Arab Spring development.

\section{A Note on the Center as a Theoretical Framework}

I define the concept of the "Center" as a shifting ideological space that started to develop in North Africa in the aftermath of the 2010-2011 uprisings ignited in the region. In my article "The Center: a Post-Revolution Space for Women's Movement in North Africa" (2016), I introduced this concept as a framework for understanding the historical trajectory of women's movements in the region. In this article I revisit this concept and suggest it as a framework for understanding the emerging female feminist voices and their distinctive contributions to the development of feminisms and gender studies in North Africa.

Prior to the uprisings in North Africa, and more precisely during the 1990s and 2000s, fierce ideological public debates raged between secularists and Islamists. While the secularists (al-'ilmâniyyin) espouse modernist views, individual freedom, liberal values and stress the separation of religion and politics in the public sphere, the Islamists (al-Islâmiyyin) espouse conservative views and seek to Islamize the public space, which they perceive as "too liberal." Significantly, the core tension between the two camps revolved around women issues: their dress, their behavior, and how much freedom they could be granted in the public sphere. The public debates in the Maghrib were ignited by the arrival of political Islam in North Africa (around the mid-1980s) and supported by the already rampant ideology of the Muslim Brotherhood, which was founded in Egypt in 1928. ${ }^{4}$

The ideological debates had economic roots and a political face. On the economic level, unemployment among youth was soaring, especially among the population age fraction of 16-30, which constituted the largest age group (nearly one out of five citizens in this region). On the political level, nepotism, corruption, and lack of accountability in the midst of a spectacular spread of political Islam and a backlash on freedom of speech created deep frustration in North African societies. On the ground, the debates turned violent in Algeria where the 1990s decade of civil war occasioned the loss of nearly 200,000 lives (Entelis 2016). In Morocco, the debates were not violent but they were real; they were largely tempered by the function of the monarchy as both the highest religious and executive authority and the ultimate mediator and arbiter between 
opposing ideologies in the country. In Tunisia, the debates were largely impacted by the mounting Islamist al-Nahda's tone in the diaspora.

With the coming of the so-called "Arab Spring", which started in Tunisia and quickly spread to Egypt and other countries in North Africa and beyond, an ideological middle-ground space between the secularists and the Islamists started to take shape (which I call the Center). This new space is neither secularist per se nor Islamist per se and is not a center space between the two ideologies; the Center encompasses and transcends the secularist and Islamist ideologies and may be seen as a space of diversity where other active actors enter the scene and create interaction: Berber (Amazigh) activists, radical secularists, radical Islamists, secular feminists, Islamic feminists, and so on; and where networking between these actors is enhanced by the quick and efficient crosscommunication that social media allows. Hitherto marginalized voices and topics are now pulled together to the Center and made to "converse" with, among other parties, Human Rights Non Governmental Organizations, transnational movements, and grassroots associations.

I qualify the Center as "shifting" because the actors in it are neither monolithic nor dichotomous (secular vs. Islamist) but polyvocal and multidimensional. Likewise, the topics that these actors address and the strategies/practices used to address these topics are flexible and amenable to interconnectivity with other topics and strategies. Similarly, as social media may be considered a public or private space, the Center may be seen as both a public and a private space. In parallel, the meaning of key older conceptssuch as the "nation state,"political loyalty,alliances, and leadership is shifting. The shifting nature of the Center is also due to a constant spirit of protest among the youth, which was brought about by the democratic movements that initially ignited the uprisings, before the latter were highjacked by the Islamists. The fact that the spirit of protest continued well after theinitial movements that started it were substantially weakened means that the Center as a space answers a real need in the North African public discourse. This article focuses on a specific category of the new voices that have emerged in the Center: the young female voices, who, although they do not selfidentify as feminists or gender studies experts, are transforming feminism and gender studies from within.

\section{Institutional Instrumentaization: Women's rights in North Africa}

The institutional instrumentalization of women's rights by the state in the countries of North Africa started on the eve of the independence of these countries in the mid-twentieth century. This instrumentalization has been widely documented in the postcolonial era (See: Mernissi 1975, 1987; Moghadam 1993; 
Lazreg 1994; Al-Ali 2000; Charrad 2001; Sadiqi 2014; Clancy-Smith 2017). Taking various routes and using different disciplinary perspectives, these studies have detailed how the state in North Africa constructed Islam and Standard (written) Arabic ${ }^{5}$ as state religion and language, respectively, and how they instrumentalized religion and language to establish a gendered hegemony on women's legal rights, modernity, education, etc. through appropriate institutions. The Islam of the state is basically legal in nature and Standard Arabic (the language of the Qur'an) is not a mother tongue in a region where female illiteracy is still very high. ${ }^{6}$ By positioning itself as the sole initiator and detainer of the legal system, the state became the controller of family law reform. Family laws in North Africa concern all the components of society: the legal, political, theological, socio-cultural, and intellectual. On the legal level, they are central pieces in the countries' judicial arsenals as they touch on practically all the other aspects of their legal systems; on the political level, women's judicial status in the family is linked to demands for democracy premised on citizenship; on the sociocultural level, these laws are associated with the controversial notion of "emancipation/will""; and on the intellectual level, they are at the heart of the continuous antagonism between conservatives and modernists. ${ }^{8}$

A significant amount of scholarship has shown that post-independence family laws in North Africa (also referred to as "Personal Status Codes") were heavily patriarchal and detrimental to women's status in society, even in Tunisia ${ }^{9}$ where the relatively progressive reforms suffered for a long time from lack of full implementation. Various reasons for the state's free hand over women's rights were given: First, the newly independent societies were largely illiterate and economically weakened and hence needed the protection of the state. Second, the state-builders needed to reassure the pervasive tribal mind-set and the nationalist patriarchs that the traditional structure of the family would be maintained. Third, it was important for the new state to be part of the larger Islamic and monolingual Umma (Arab nation), seen as a source of strength, moral solidarity, and continuity. Although Berbers (Amazigh) ${ }^{10}$ constituted a substantial component of nationalism and resistance to colonization as today's social history shows, the official narratives in the region attributed independence to urban male Arab nationalists. Consequently, women, the large rural population, as well as Berber and Arabic dialects were not on the agendas of the state-builders (Camps 1980; Ennaji 2005; Maddy-Weitzman 2011).

The state continued to instrumentalize women's rights and resist reform even after urban women had benefited from massive schooling and even after these women started to actively participate in the economic growth of their countries. For many decades, family laws in the region were presented as sacred and not open to change. It took the countries of the region decades of individual and 
collective militancy at the political, civil society, and academic levels to achieve the present-day reforms. It is only in the twenty-first century that some breakthroughs were made (Grami 2008; Sadiqi 2008; Bernard-Maugiron and Dupret 2012; Kelly 2010).

It is against this relative stalemate caused by the monopoly of the state on the timing, and implementation of the reforms that new feminist voices demanding change started to emerge in the post-Arab Spring era. For these new voices, the inaccessibility of equal legal rights for women in addition to the lack of political will in implementing reforms were behind women's slow progress. For these voices, women's participation in the labor force and their share of paid employment have remained low despite women's rising educational attainment, household economic needs, and international advocacy for women's economic participation and empowerment. ${ }^{11}$ The new voices acknowledge that women's movements in the region have become genuine social movements and that they have negotiated power with the state but could achieve only what the state allowed them to. The state reinforced the already existing patriarchal norms and produced discriminatory state policies not only in labor force participation but, most crucially in gender relations and public decision-making.

It is against this overall background that new voices emerged in the aftermath of the Arab Spring. For these voices, meaningful headway could not be achieved because the state controlled reform of the family laws in the region by encouraging, instigating, initiating, abrogating, or refusing these reforms according to the overall historical and political climate. It is this total monopoly of the state on women's rights that these voices are contesting. Being more religiously literate than the older generation, the new generation is more vocal about Islam not being the cause of the repression of women. They draw attention to political agendas behind using Islam as a pretext for arguing against women's rights, and see attacks on Islam as a way of dehumanizing Muslim women and denying their agency. They also point to patriarchal and political structures within which women are oppressed and denounce patriarchal interpretations of the Islamic tradition as a real danger. In sum, they believe that gender equality should be targeted irrespective of ethnicity, race, religion, or culture. The question to ask at this juncture is: Who are these new female voices? What are the topics they address? And what are the strategies and practices they use?

\section{Who Are the New Female Voices?}

\section{A Note on Methodology}

The contents of this section are partly based on fieldwork that I conducted in 2017-2018. Part of this fieldwork is a selected sample of 55 young female 
scholars, activists, and politicians from Morocco (17), Algeria (10), Tunisia (15), and Egypt (13) that I interviewed. My interviews were semi-informal and lasted about one hour each. I conducted virtual interviews (via Skype) with the women from Algeria, Tunisia, and Egypt. Interviews with Moroccan women were conducted in person, and the sample from Morocco was bigger since this is my place of residence where where I could reach out to young women from the regions of Fez, Casablanca, and Rabat. The interviewees were often but, not always, urban young girls, university students, young scholars, and (virtual) activists. They are multilingual, using Arabic dialects, Berber (Amazigh), French, and English, and their means of communication are mainly social media. Most of my interviewees do not always self-identify as feminist and do not invoke the state as an ally. Some of them have no knowledge ofthe historical battles of feminists in the region and, hence, they answered my questions without preconceived ideas. Although they discussedequality and dignity, ${ }^{12}$ reclaiming the street, ${ }^{13}$ and benefited from their predecessors' accumulation of knowledge, my interviewees were more pragmatic and less ideological than the previous generations.

My interviewees fall between the ages between 21 and 35. Most hold a university degree and some of them are employed. I centered my interviews on three basic questions: (1) Do you consider yourself a feminist? Why? (2) How do you judge the work of the former generations of feminists? (3) What do you consider as new in your work, activity, etc.? In conducting the interviews, I abided by clear research ethics: For example, I told each participant that I would respect confidentiality and privacy. Some of them consented to be recorded and some did not. In the latter case, I took notes and observed body language. All the participants signed a consent form to be interviewed.

In addition to the interviews, I organized a workshop in Fez on June 3, 2018 where my Moroccan interviewees and 10 guest speakers from the older generations participated. Two women (one from the older and one from the younger generations) from Algeria, Tunisia, and Egypt also participated.The aim of the workshop was to encourage the older and younger female voices to speak freely about current women's issues. During the workshop, the debates were heated at times. One of the issues that created lengthy discussions was family law. Whereas the older generation expressed its trust in lobbying with the state, the younger generation tended to think that lobbying takes time and is often sterile. Both younger and older feminists were conscious of the multiple roles they were playing and bothended up with moments of self-criticism. Likewise, the younger generation acknowledged the central importance of knowledge provided by the older generations, and the older generation felt the need to bridge 
the gap with the younger generation, listen to their suggestions, and engage with their lines of thought.

I supplemented my interviews and workshop with a careful study of several samples of e-newspaper debates on women's issues and paid particular attention to the various comments that the readers provided. One such e-newspaper is the Moroccan Hespress. I also used my own readings on the new generation of feminists, as well as observations and frequent discussions and interactions with young women at the gym, hairdresser, family gatherings, etc.

\section{Analysis: New Topics, New Strategies}

New female voices address new topics and new strategies that differ from those of the previous generations of female feminists. The new topics are related to identity, legal Islam, and body issues, and the new strategiesand practices include virtual protests, leaderless campaigns, and art. The novelty of these topics and strategies is gauged against the topics and strategies of older feminist voices.

New Topics: Three new topics stand out in the contents of the emergingfemale voices: the Berber (Amazigh) issue, a transnational and virtual view of legal Islam, and sexual harassment.

Identity Issues: The identity issues that emerged in youth conversations were very much associated with rural areas (as opposed to the urban ones). This association is most apparent in Morocco, where it has crystallized in the emergence of Berber (Amazigh) feminist NGOs. It is true that the first such NGO appeared at the beginning of this century, but more and more such NGOs followed the institutionalization of Berber as an official language in 2011, and more and more of them are making their voices heard. Nine such NGOs are now established organizations: Association TinhinanKhemisset, Voix de la Femme Amazighe, Association Anaruz, Association Tinhinan Tiznit, Association Thaziri, Association Tamghart, Association Tayri, Observatoire Amazighe des Droits et Libertés, and Forum des Femmes Amazighes de Tamazgha.

These NGOs address issues that were sidelined by the mainstream Moroccan feminist movement, namely, gender in relation to language, identity, and geographical origin (that is, whether it is urban or rural). When asked, the coordinator of one of these organizations deplored the fact that secular Moroccan feminists target elite urban women to the detriment of rural women, and Islamic feminists focus on religion and fail to capture the "Berber" element which, for her organization, constitutes the historical basis of the Moroccan social fabric that differentiates it fromthe Middle Eastern social fabric. Most of the female 
Berber NGOs do not self-identify as feminist organizations, use Tifinagh (the Berber alphabet) in addition to Arabic or French, and position their work within the framework of human rights, diversity, and freedom of expression.

In their literature, these NGOs highlight the double marginalization of a large portion of rural Berber women and underline the fact that these women are caught between patriarchal state institutions and language hegemonyin the public sphere, on the one hand, and oriental and occidental values, on the other hand. In these complex interactions, the female Berber identity is felt by many interviewees to bemarginalizedat a time when Morocco officially prides itself on being a millennial country with ancient Berber roots. For these NGOs, it is women, more than men, who kept the language and the culture it carriesalive. For most of them, Berber language and culture survived because of women not because of the state.

Female Berber NGOs position themselves between the local and the global by emphasizing "authentic" values and advocating the linguistic, political, cultural, economic, social, and civil rights of women in accordance with international conventions. In so doing, they circumvent the state and seek to make their voice heard transnationally.However, although female Berber NGOs have common goals, they do not have the same choices. Whereas four of them are located in big cities, two are located in towns, and three in rural areas. As location interacts with social class and ability to interact with larger local and transnational feminist and human rights NGOs, ability to raise funds, exposure to media, and proximity to the makhzen (central power in Morocco), urban NGOs have more privileges than rural ones. Whatever their choices, female Berber voices constitute a newcomer to the larger Berber movement. This does not only add to the Berber movement a gender aspect, but it expressesa new type of voice in the larger post-revolution Center of protests.

A transnational Virtual Legal Islam: Although legal Islam constitutes the common source of family laws and reform in North Africa, most of the literature on this topic has been anchored within the national boundaries of specific countries. However, after the 2010-2011 uprisings, more and more voices of younger female (and male) generation are expressing support for transnational movements that call for equality in family laws such as Musawah (Equality), WISE (Women's Islamic Initiative in Spirituality and Equality), WLUML (Women Living Under Muslim Laws), the Oslo Coalition on Freedom of Religion and Belief, Karama (Dignity), etc. Islamic feminists in these transnational networks have been carving out non-patriarchal interpretations of key verses in the Qur'an that are generally used by patriarchal schools to suppress women. Through rigorous interpretation methodsthey have been able to demonstrate that Qur'anic texts can be read differently. It seems that while the 
previous generations saw a closerelationship between legal Islam and the nationstate, the new voices are conscious of the centrality of legal Islam in family laws but seek to eschew this association altogether.Instead, many of them, including my interviewees, underline the importance of transnational interactions and consultations in matters of legal Islam. For them, transnational legal Islam is more conducive to equality and social justice. Interestingly, these young women do not equate transnational interaction/solidarity with globalization; on the contrary, they express resistance to globalization and underline the importance of local contexts and inclusion in legal matters. When asked to explain this "conundrum", they provided reasons like the "tedious slowness" of the state in implementing reforms and the "attested power" of international pressure on states. This attitude is corroborated by facts on the ground. For example, who could imagine at the beginning of this century that a young Tunisian journalist/scholar could openly defy President Essebsi's call for equality in inheritance in the way Asma Ghribidid:

I refuse to accept the destruction of democracy as a price for this achievement. We should be able to have equal rights as women without having to sacrifice our right to good governance, rule of law and justice for the victims of oppression. We should not have to choose Essebsi's embrace of faux feminism even as he chips away at the foundations of democracy is part of a larger pattern. He is following the same strategy as the dictators he once worked for: trumpeting progress on women's rights to hide his anti-democratic practices from the eyes of the West. (Ghribi 2017 , n. page)

According to my fieldwork, the new voices seem to be inclined to both keep legal Islam as part of their everyday lives and a source of answers to their daily personal and social dilemmas, and seek relevant information and solidarity transnationally. It is this inclination that pushed feminist scholars like Moroccan Asma Lamrabet and Meriem Yafout to come up with their own equality-based interpretations of the Qur'an and weave links with the Musawah transnational movement. It is important to state here that some older-generation feminist female scholars like Moroccan Fatima Mernissi started to criticize elite male interpretations of the Qur'an and Hadith (Prophet's Sayings) as inherently patriarchal and detrimental to womenas early as the 1980s (see Mernissi 1987). In this respect, at least in Morocco, the gap between older and younger generations is to some extent being bridged. ${ }^{14}$ In other words, the older generation's trend of interrogating legal Islam with the aim of fostering women- 
friendly interpretations of Islamic law is increasingly attracting attention among the younger generations of female (and male) feminists. The difference is that unlike the former generations, the latter one uses social media and produces instant impact.

Sexual Harassment: In addition to Berber identity issues and transnational, virtual legal Islam, body issues fare high in the topics addressed by emerging female feminists. Although my interviewees agreed that body issues are not absent in the rhetoric of older women's movements in North Africa, they often deplored that this rhetoric was "too timid" and "rather indirect." Younger voices seem to be more inclined than older ones to break long-standing taboos, oftentimes in defiance of the state and the religious establishment. Of the various taboos that attracted their attention, the most salient is sexual harassment (altaharrush al-jinsi).

Most women I interviewed denounced sexual harassment as "crippling" and "insulting" and stated that this harassment is experienced daily by both veiled and non-veiled women. It is interesting to note that, thanks to social media, some of my interviewees were aware of the various campaigns that were launched against sexual harassment in the region and that some of them supported these campaigns. It has been reported that in Egypt, for example, sexual harassment made headlines in March 2011 when a women's march celebrating Women's Day were harassed in Tahrir Square. The following day a number of arrested protestors were subjected to virginity tests. It was also reported that body disciplining as a means of socio-political control was attested in Tunisia and may be seen as a general phenomenon across the region.

The recent literature on this topic corroborates these facts.For instance, Abdelmonem examines the various meanings of "taharrush" in Egypt and argues that there is a shift in the conceptualization of this term:

The data showed overwhelming public concern in the region about the molestation and rape of children until 2006. In October 2006, a shift occurred in Egyptian posts, tied to the Eid mob sexual harassment that took place in downtown Cairo. From that point on, taharrush in Egypt signified the sexual harassment of women in public space. (Abdelmonem 2015, 1)

According to this author, this shift is mainly due to the activism of anti-sexual harassment NGOs such as the Egyptian Center for Women's Rights and community-based work such as HarassMap (a global grassroots initiative whose goal is to mobilize local communities to support peace building through intercultural dialogue). The emerging anti-sexual harassment initiatives seek to link the meaning of taharrush to more violent forms of sexual assault and rape 
and promote public resistance to the idea that taharrush signifies everyday sexual harassment. To achieve this, they point to words like mu 'akasa (flirtation) as a way of differentiating between "harmful" and "non-harmful" sexual harassment in Egypt.

Abdelmonem's differentiation between taharrush and mu'akasa may be extrapolated to the entire North African region with the same discursive hues. In Algeria, in 2015, women's groups pushed the parliament to adopt a bill amending articles of the penal code that relate to the protection of women against all forms of violence. Although this text scored some progress in the Algerian legislation despite the resistance of the Islamists of the Alliance of Algeria, it was criticized for its introduction of the concept of "forgiveness" which generally favors impunity. For Amnesty International, stipulating forgiveness ignores the reality of power relations and inequality between men and women and exposes them to increased risks of violence and use of coercive methods to withdraw their complaints. In 2016, the National Coordination of Security and Protection Officers, affiliated to the National Union of Autonomous Workers of Electricity and Gas (SNATEG), issued a statement where it accused officials within the Sonelgaz of sexually blackmailing employees in return for contracts and more advantageous working conditions.

In Tunisia, since the end of September 2017, there has been a vast campaign against sexual harassment in public transport (especially buses and tramways). Launched by women's groups, in collaboration with the European Union and the United Nations Population Fund, this campaign includes support for armbands and white and red blank bus posters with the inscription "the stalker does not go up with us," accompanied by an awareness-raising video on social networks. The campaign aimed to encourage victims to denounce abuses and the violence that sometimes accompanies them. In 2017, the Tunisian legislation on the elimination of violence against women started punishingsexual harassment by one to two yearsof imprisonment and five thousand dinars in fines.

In Morocco, according to the 2017 findings of the Office of the High Commissioner for Planning (HCP), 40.6 percent of urban women aged between 18 and 64 reported having been "victims of sexual harassment involving an act of violence."15 These aggressions are reported to have taken place in public places. In addition, several cases of sexual harassment have hit the headlines and the topic of sexual harassment was put back at the center of national debates in August 2017 when a video showing a collective sexual assault against a young woman on a Casablanca bus went viral. The government then promised a "strategy" to fight this "scourge." Hence on February 14, 2018, the Moroccan Parliament finally adopted a law (Law 103-13) criminalizing violence against 
women which was initiated in 2013. One of the major novelties of the new law is the provision of a legal arsenal and the adoption of Amnesty International's specific definition of harassment as "any form of unwanted sexual behavior, whether physical, verbal or non-verbal, with the purpose or effect of impairing the dignity of a person." Harassment can also be perpetrated through written texts, telephone or electronic correspondence, photos and/or sex-related recordings. However, there is no deprivation of liberty for these acts; only a fine of 2,000 to $10,000 \mathrm{DH}$. It is important to note that this law was criticized as "insufficient" and that it is couched in "vague language," lacks guarantees, and fails to consider marital rape as a specific criminal offense, as well as excluding the possibility of men and boys being victims. Likewise, the Alternative Movement for Individual Freedoms (MALI) regretted the impunity of marital rape in the law and deplored the persistence of retrograde and misogynistic mentalities within a parliament led by Islamists. ${ }^{16}$ Further, Amnesty International criticized this law, accusing the Moroccan government of subordinating prosecution in case of forced marriage to the filing of a complaint by the victim on the proviso that there is a risk that the victim will be subject to reprisals and that her husband or family will press her to withdraw her complaint.

According to workshop discussions amongst my informants, addressing sexual assault in North Africa is a particularly sensitive topic due to the culture of victim shaming and blaming, and also because of the ambivalence surrounding positive and negative consent in the region. The participants agreed that women in their socio-cultural context are generally expected to say "no" to a sexual relationship and mean "yes"; however, in the absence of any serious research on this topic, women's behavior may be attributed to what may be qualified as "internalized patriarchy" whereby women feel the need to support cultural expectations in order to survive, participate, and be included in maledominated spaces, or to avoid violence. This is corroborated by the fact that the NGOs that call for action against sexual harassment focus on the provision of training programs, anonymity, the protection of the victim (trauma support and therapy for the victim and the condemnation g of the accused's "presumed" innocence in a dominant culture that still needs to foster a safe environment for the victims), as well as the creation of signed anti-harassment policies for all employees. They also call for preventative strategies, with more debate involved when considering potential consequences and punishments for the accused.

New Strategies: The strategies adopted by emerging women include virtual protests, leaderless campaigns, and art.

Virtual Protests: Using technology, especially the Internet, WhatsApp, Facebook, cell phones, and social media is a new strategy in feminist militancy 
and protest across North Africa. This strategy is generally perceived as a democratizing tool that facilitates action (for example e-meetings) and rhetoric (ability to expose one's ideas freely).It alsoallows a wide and quick circulation of information, hence creating instant interaction, discussions, correction of points of view, adaptation, or withdrawal from discussions. Although this strategy is more available to urban young women, it is increasingly spreading to rural populations. Young women in rural areas do not need to be highly educated to use WhatsApp or Skype, and these are becoming more affordable with the availability of cheap second-hand smart phones. Since 2011, more and more young women are involved in virtual campaigns against, among other things, governmental decisions and engaged in e-instructions to, for example, join street protests and maketheir voices heard. Compared to older female strategies, such as letter writing or phone calls that took more time and needed more organizational logistics before protest demonstrations could take place, this is a new and significant development.

On the other hand, virtual protests are having a big impact on language use. Whereas the older generations used sophisticated written languages like Standard Arabic, French, or English, the younger generations are increasingly using Arabic dialects and Berber in their virtual interactions. The impact of this linguistic shift is yet to be researched.

Leaderless Campaigns: Another strategy that the younger generation is using is a quasi-systematic conscious avoidance to appoint a leader for their campaigns and movements. This is to be contrasted with the older strategy of rallying around a charismatic feminist leader. Leaderless campaigns and movements enhance anonymity and inclusion and hence create a snowball effect where more and more youth are attracted to join, as one interviewee told me. In other words, just as virtual protests are democratizing young women's militancy, lack of leadership is democratizing their involvement in action and rhetoric.

Art: Art is another strategy of resistance that the post-uprising generation of women is using, especially in Egypt and Tunisia. In these two countries, young women are using cultural forms as a means of protest and resistance. They are using graffiti, (wall) painting, street performance, etc. as mediums of artistic expression. This fact is corroborated by Nevine El Nossery (2016) who argues that during the 2010-2011 Arab Spring, Egyptian women used graffiti and street performances as "urban art" that allowed them to access public space and express their protests, and calls this use a "parallel revolution" in the sense that women asserted themselves as "creative agents" in the eyes of a society that still regards them as "docile" and "passive." Indeed, art seems to be part of Egyptian women's political activism in the post-uprisings period. Through art, many 
youngwomen in this country changed their role "from beauty to power" (Hack 2012, n. page); they used female forms to express future hope and fear. For example, female mural artists, such as Alaa Awad, depicted the story of the Egyptian Revolution through Pharaonic motifs: Timeless ancient female icons of Egyptian history such as Pharaonic queens were painted as dancing figures amid uncertainties of the Revolution. Other women walked on the street wrapped in plastic to evoke "modern packaging, Egyptian mummies, and the conformity of religious veiling" (Hack 2012, n. page).

In Tunisia, works of art that used the revolution as a subject proliferated after the downfall of the Benali regime. ${ }^{17}$ While male productions constituted a way of emulating iconic revolutionary symbols and exploring the complex challenges that Tunisia was facing, women used art to express the female self in the public space. In addition, photography exhibits became abundant and music was also used. Street art (Keskes 2018), especially murals, was a way of reclaiming public spaces that were still controlled by the government,allowing artists and ordinary female citizens to express themselves freely for the first time in decades (Galliot 2011). Individual or collective mixed-sex artists, such as the students-run ahl alkahf (People of the Cave), used local revolutionary symbols to produce themes of the revolution such as the portrait of Mohamed Bouazizi; others used international (especially Latin American) revolutionary symbols to produce art. Such productions were well covered up and mediatized. "Through my art, I today defend the Arab woman, Muslim, artist, veiled and free! What I am, in fact," states Oumema Bouasseda (known as Ouma), a 22-year-old Tunisian woman who weaves her canvas by giving life back to walls, and stairs (Jeune Afrique 2016). Oumema and other women use Graffiti as a "megaphone" to send messages tainted with anger, irony, humor, or sometimes poetry, to challenge passers-by. Many young women, faced with poverty, unemployment, and corruption still rife today, continue to splash urban walls with expressions of protest ("Jeune Afrique" 2016). In March and August 2016, young people from the association "Les Volontaires" (Volunteers) were invited by the Tunisian National Railway Company (SNCFT) to repaint several subway stations with the goal of both beautifying the premises and raising environmental awareness.

According to the workshop discussions I conducted, young Egyptian and Tunisian participants reported that female artists considered their art "undocumentable" in a linear fashion because of the absence of hierarchy in it. While resisting being labeled "feminists" or being identified as "only women", these new artistsare reported to seek recognition as citizens struggling alongside men for their right to freedom, dignity, and justice. The workshop debates also revealed that women's art in the aftermath of the uprisings is a way of reconciling with the ancient past. Indeed, while the cultures of North Africa are thousands 
of years old, the post-uprising period brought about a new relationship with this ancient legacy, a fact that young promoters of the Berber language and culture support. Art is generally believed to be related to freedom of speech. Informants from Egypt and Tunisia reported that the censorship under Mubarak and Benali was being replaced by unprecedented freedom of expression and questions on how to use this freedom. This last statement may not be totally true for Egypt today,which is witnessing a backlash on freedom of speech, but in Tunisia the democratic change seems to be ongoing according to my informants.

\section{A Reading of the New Female Voices}

A consideration of the findings I could synthesize from both the answers and the body language of my informants led me to the conclusion that although most of my young informants did not self-identify as feminists or gender experts, the contents of their topics and the nature of their strategies are feminist in the sense that they both address women-related issues (sexual harassment, gender equality in inheritance, etc.) and use strategies that promote them as women (e.g. art in the public space). I would qualify this new generation as transformative, in the sense that it is recreating new brands of feminism from within North Africa. Taken together, they constitute new distinctive voices whichdo not fit in the older feminist paradigms of the region. Some of the characteristics of these new voices are better appreciated when compared to their predecessors.

Seen against the previous generations of feminist female voices in North Africa, the emerging feminist female voices seem to be more polyvocal both horizontally and vertically. Horizontally, the topics addressed by the younger generation do not have a common core when compared to the earlier demands, which consistently revolved around the family law. Vertically, the new voices are not solely urban and highly educated as was the case with their predecessors; many of them are rural or with a rural background. Likewise, compared to their elders, who capitalized on university degrees, the new voices may be less knowledgeable of feminist theory and methodology, but they are more religiously literate and more pragmatic. Religious literacy was exhibited by practically all my interviewees. For example, unlike their predecessors, and regardless of their political and ideological inclinations, my interviewees are more aware of the history of Islam, the various schools of jurisprudence, and the various debates on religion, and many of them engage in religious discussions online.

On the other hand, the younger generation's topics and strategies point to a clear desire to transcend the older topics and strategies where lobbying with the state was central. Their new topics and strategies have been greatly influenced 
by the Arab Spring rhetoric and practices such as leaderless campaigns and the use of cell phones and social media. The private nature and anonymity of social media partly explain the individual boldness of the new voices and their lesser trust in specific leadership, institutions, or loyalty to political alliances. Lack of leadership and anonymity may be seen as a reaction to the hegemonic language of traditional political parties where many older-generation feminist women sought power. By discarding charismatic leadership, the younger women seem to eschew a search for power and opt instead for a defiance of this power (Abouelnaga 2016).

With respect to the goals of the emerging messages from the younger generation, three trends may be discerned: the search for a new social contract with the state in which the latter ceases to hold monopoly over the timing and density of gender-based (legal) reform; a desacralization of (political) alliances; and a destabilization of an internalized patriarchy.

\section{A Search for a New Social Contract}

The post-independence social contract between the state and the populations in North Africa is weakening after the uprisings. The downfall of three state leaders: Zine al-Abidin Benali in Tunisia, Hosni Mubarak in Egypt, and Muammar Gaddafi in Libya is the obvious proof. Algeria was spared because of a decade's civil war in the 1990s (Hagelstein 2008) and Morocco was spared because of the promulgation of several gender-based reforms in the first decade of the twentieth century (Pollock 2013). The weakening of the state in the region brought about a frontal and direct clash between the long-time marginalized populations and the institutional authority. For the first time in the history of the modern state in North Africa, the protests become heavily feminized, not only during the mobilization phases but also, and meaningfully, afterwards. This feminization is facing serious challenges but it is persistent. The main challenge is the rise of religious parties that threaten the hard-won gains of women in the region.

With this background, it is easy to see that the subtext of the new female voices is the need to be vigilant and wary of the reversal of progress. Many ofthe new voices capitalize on the protection of women's citizenship rights, arguing that these can be safeguarded only if religion is separated from the state. In addition, for the new female voices, the search for a new social contract should include identity. On this particular question, the new voices seek to deconstruct the principle of homogeneity which resulted in paradoxes like the postindependence marginalization of Berbers in the name of modernity and the postuprisings elevation of the language to the status of official language in the name of modernity. Feminist Berber NGOs are indeed producing a counter discourse 
of real significance to the new social pact: They confront both Islamic feminists, whom they accuse of squeezing women's multiple identities into their religious identity, and secular feminists, whom they accuse of focusing on urban areas.

Overall, the new female voices seek to push the state to its limits. In so doing, they are both negotiating and creating new spaces in the North African feminist rhetoric and movements. They are challenging both religion- and secular-based feminist agency. These women no longer believe in the strong national discourses that propagate a fixed image of gender that considers women to be the symbols of the nation. They are defying nationalism and creating new subnational identities in the wake of the dramatic fall of Arabism and reinforced globalization. The new female voices are challenging state power by creating what may be termed "micropolitics," that is, merging the private and public with the personal and political. This is rendered possible by a combination of leaderless campaigns where individual women work from their own perspectives and highlight their own specific concerns. It is micropolitics that allowed the visibility of a multitude of individual concerns that women of the older generations would hide as "private." In so doing, the new generation of women rejects the normative definition of gender (as designed within a legal framework that the state controls); they are seeking a new political, economic, and legal order that works for all citizens whatever their concerns.

\section{Creation of Transversal Alliances}

As explained previously, the two-decade long ideological debates that preceded theArab Spring witnessed opposition between two distinct camps: the secularists and the Islamists. Supporters of one camp were expected to remain loyal to it and continuously defend themselves against their opponents; the alliances were "either or" and never "both". The differences between the two camps were constantly hammered in the media, conferences, etc. This dichotomy fortified the state, which played the role of the mediator in cases of tension between the two camps. However, after the uprisings, a sense of pragmatism and distance from ideology started to emerge and gradually weaken the principle of loyal alliance to one particular camp. Through a multitude of voices, topics, and strategies and the increasing ease of communication, the youth started to reach out to other youth regardless of their ideological background. This led to the rise of the Center as a space of conversation across real or fictional borders.

\section{Conslusion: Revisiting the Center}

The framework of the Center presented at the beginning of this article may help us understand the post-Arab Spring development in North Africa as outlined 
in the sections above. These sections have shown that this moment is characterized by six main findings: young women's increasing visibility and heterogeneity, new topics (identity issues, a transnational and virtual view of legal Islam, and sexual harassment), new strategies (virtual protests, lack of leadership, and art), a search for a new social contract, the creation of transversal alliances, and the destabilization of an internalized patriarchy. The proliferation of these topics and strategies could not have been real without the existence of the new Center spacewhich attracts young women from various geographical origins (urban and rural), classes, professions, levels of education, and social statuses. It is the heterogeneity of these women which makes the concept of the Center relevant.

Young women's increasing visibility and heterogeneity has further been made possible by the shifting nature of the Center and the prominent place of social media in it. Unlike previous decades, more and more female voices can access the spaces of authority and make their voices heard. Older hegemonic rubrics like "women of the Third World" or "Muslim Women" no longer reflect the new circumstances of the new generations of women in North Africa and no longer have a place in the Center. The new goals that the younger generation is fixing for themselves (a new social impact, transversal alliances, and the destabilization of internalized patriarchy) are new and appealing; they are also deeply transformative and far-reaching and deserve further research and scrutiny. These transformative goals callfor novel ways of thinking and theorizing about feminism and gender in a predominantly young and promising North Africa.

\section{Endnotes}

${ }^{1}$ In this article, "North Africa" is used to refer to the following countries on the basis that they produced robust women's rights movements: Egypt, Tunisia, Algeria, and Morocco. The last three countries are also referred to as the "Maghrib" (Sadiqi, Nouaira, Elkhouly and Ennaji 2009).

${ }^{2}$ In my upcoming book Daesh (ISIS) Ideology As a Reflection of Gender: An Insider Perspective, I demonstrate how Daesh ideology instrumentalizes the hard-won women's rights to survive.

${ }^{3}$ Although both women and men are involved in the instigation and performance of these changes, I will focus on women in this article.

${ }^{4}$ The type of political Islam alluded to here has immediate roots in the ideology of the Egyptian Muslim Brotherhood (founded by Hassan al-Banna in 1928). This ideology saw ups and downs under Nasser's rule (1956-1970), al-Sadat's rule (1970-1981), and Mubarak's rule (1981-2011). 
${ }^{5}$ Berber (Amazigh), the indigenous language of North Africa, became an official language in Morocco on June 17, 2011 and in Algeria on February 11, 2016.

${ }^{6}$ Female literacy was very low in the countries of North Africa on the eve of their independence (Clancy-Smith 2017). Even today, official statistics of illiteracy among Moroccan women is almost 60 percent (Larhouasli Marrakchi 2008).

${ }^{7}$ Generally speaking, North African societies resist women's emancipation as they associate it with women's will (understood as "distance from the family"), which they resist while appreciating women's intelligence, as the latter is perceived as an added value to the family.

${ }^{8}$ Family laws in North Africa are all-encompassing texts that constitute both a subject of their own and a means of studying other topics such as changing notions of state authority, individual decision-making, gender practices, family planning, and family size.

${ }^{9}$ The first Tunisian family law (Personal Status Code) abolished polygamy and Tunisia remains the only country where this practice is punishable by law.

${ }^{10}$ In this article, I use "Berber" and "Amazigh" interchangeably.

${ }^{11}$ Indeed, women's participation in labor force in North Africa has decreased between 1990 and 2014 and the average remains 25 percent (see IMF 2017).

${ }^{12}$ For example, "karama" (dignity) was invoked as early as 1946 by Akhawat al-Safa (Sisters of Purity), the first women's association in Morocco.

${ }^{13}$ Women's movements in North Africa have historically used street protests to demand rights.

${ }^{14}$ Fatima Mernissi participated in some Musawah meetings (Personal Communication, October 2012).

${ }^{15}$ See https://www.hcp.ma/downloads/.

${ }^{16}$ See https://afrique.lalibre.be/15359/le-maroc-se-dote-dune-loi-contre-les-violencesfaites-aux-femmes/.

${ }^{17}$ An example here is Aicha Hamdi ; see https://fineartamerica.com/profiles/aichahamdi.html.

\section{Works Cited}

Abdelmonem, Angie. 2015. "Reconceptualizing Sexual Harassment in Egypt: A Longitudinal Assessment of el-Taharrush el-ginsyin Arabic Online Forums and Anti-Sexual Harassment Activism." Kohl: A Journal for Body and Gender Research 1(1), pp. 23-41.

Abouelnaga, Shereen. 2016. Women in Revolutionary Egypt: Gender and the New Geographics of Identity. Cairo: American University.

Al-Ali, N. 2000. Secularism, gender and the state in the Middle East: the Egyptian women's movement, Vol. 14. Cambridge: Cambridge University Press. 
Bernard-Maugiron, Nathalie and Baudouin Dupret. 2012. (Eds). Ordre public et droit musulman de la famille. En Europe et en Afrique du Nord. Bruylant: IRD Editions.

Camps, Georges. 1980. Les Berbères, aux Marges de l'Histoire. Paris: Hespérides.

Charrad, Mounira. 2001. States and Women's Rights: The Making of PostColonial Tunisia, Algeria, and Morocco. Berkeley, CA: University of California.

Clancy-Smith, Julia. 2017. "North Africa and France: Imperialism, Colonialism, and Women, 1830-1962." Oxford Research Encyclopedia of African History. Oxford University Press, USA.

Ennaji, Moha. 2005. Multilingualism, Cultural Identity, and Education in Morocco. Boston: Springer.

Entelis, John. 2016. "The Algerian Conundrum. Authoritarian State, Democratic Society." Prospects for Political Reform Post Arab Spring: Beyond Islamists and Autocrats. The Washington Institute for Near East Policy.

"En Tunisie, des graffitis engagés et citoyens." 2016. Jeune Afrique. https://www.jeuneafrique.com/361050/societe/graffitis-tunisie-murs-seentendre/.

Galliot, Lorena. 2011. "Grafitti Artists Show Their Support for the Tunisian Revolution." France 24. https://observers.france24.com/en/20110606graffiti-artists-show-support-tunisian-revolution.

Grami, Amel. 2008. "Gender Equality in Tunisia", British Journal of Middle Eastern Studies, vol. 35, $\mathrm{n}^{\mathrm{o}} \quad 3, \quad 2008, \quad$ p. 349-361 (DOI 10.1080/13530190802525148).

Ghribi, Asma. 2017. "Don't Fall for the Tonisian President's Fake Feminism." Washington Post. https://www.washingtonpost.com/news/democracypost/wp/2017/10/03/dont-fall-for-the-tunisian-presidents-fake-feminism/.

Hagelstein, Roman. 2008. "Explaining the Violence Pattern in the Algerian Civil War." Working Paper 43. http://www.hicn.org/wordpress/wpcontent/uploads/2012/06/wp43.pdf.

Hack, Susan. 2012. "The Changing Role of Women in Egyptian Art: From Beauty to Power." CNTraveler. https://www.cntraveler.com/galleries/201203-08/egypt-cairo-revolution-women-in-art.

Hamdi, Khadija. 2011. On the Path of Contemporary Art. http://www.ismailbahri.lautre.net/files/on-the-path-of-tunisian-art-en2011.pdf.

Karshenas, Massoud. 1994. Macroeconomic Policies, Structural Change and Employment in the Middle East and North Africa. Geneva: ILO. 
Kelly, Sanja, ed. 2010. Women's Rights in the Middle East and North Africa: Progress Amid Resistance. New York: Freedom in the World.

Keskes, Donia. "Le street art en Tunisie après la révolution !" https://www.tunideco.net/3206/la-liberation-post-revolution-street-arttunisie/.

Larhouasli Marrakchi, Nora. 2008. "A Case Study of Women's Education Within the Moroccan Development Model." The Journal of North African Studies 13(1): 55-73. DOI: 10.1080/13629380701550154.

Lazreg, Marnia. 1994.The Eloquence of Silence:Algerian Women in Question. London: Routledge.

Maddy-Weitzman, Bruce. 2011. The Berber Identity Movement and the Challenge to North African States. Austin: Texas University Press.

Mernissi, Fatima. 1987. The Veil and the Male Elite: A Feminist Interpretation of Women's Rights in Islam. Paris: Editions Albin Michel.

Mernissi , Fatima. 1975. Beyond the Veil. Male-Female Dynamics in Modern Muslim Society. Bloomington, Indiana University Press.

-----. Personal Communication. October 2012.

Moghadam, Valentine. 1995. "The Political Economy of Women's Employment in the Arab Region." In Gender and Development in the Arab Region, edited by Nabil Khoury and Valentine M. Moghadam. London: Zed Books.

-----. 1993. Modernizing Women: Gender and Social Change in the Middle East (Women and Change in the Developing World). Boulder, USA: Lynne Rienner Pub.

E1 Nossery, Nevine. 2016. "Women, Art and Revolution in the Streets of Egypt." Women's Movements in Post-"Arab Spring" North Africa, edited by Fatima Sadiqi, New York: Palgrave Macmillan, pp. 143-158.

Pollock, Pollock. 2013. The Journal of International Security Affairs. The Washington Institute.

Sadiqi, Fatima. (ISIS) Ideology As a Reflection of Gender: An Insider Perspective. Forthcoming.

-----. 2016. "The Center: A Post-Revolution Space for Women's Movements. Morocco as an Example." Women's Movements in Post-" Arab Spring" North Africa. New York: Palgrave Macmillan, pp. 15-30.

-----. 2014. Moroccan Feminist Discourses. New York: Palgrave Macmillan.

-----. 2008. "The Central Role of the Family Law in the Moroccan Feminist Movement." The British Journal of Middle Eastern Studies. 35 (3): 325-37.

Sadiqi, Fatima, Amira Nowaira, Azza ElKholy, and Moha Ennaji. 2009. Women Writing Africa: The Northern Region. New York: The Feminist Press. 